\title{
Development of wind-hydrogen coupling system
}

\author{
Wu Tao ${ }^{1,2, a}$, Hu Shuju ${ }^{1, b}$, Li Fenglin ${ }^{1, c}$ \\ ${ }^{1}$ Institute of Electrical Engineering Chinese Academy of Sciences, Beijing 100190, China \\ ${ }^{2}$ University of Chinese Academy of Sciences, Beijing 100149, China \\ awutao@mail.iee.ac.cn, bhushuju@mail.iee.ac.cn, clifenglin@mail.iee.ac.cn
}

\begin{abstract}
Keywords: wind-hydrogen coupling, hydrogen production, hydrogen storage, topological structure, coordinated control

Abstract. This paper presents an overview of the wind-hydrogen coupling system(WHCS), as an effective method of solving wind power accommodation, WHCS has great economic, social and environmental benefits, which has been attached great importance to and promoted widely. The paper introduces the basic structure of the WHCS firstly, then by summarizing the latest research and development status around the world, the key technologies involved in the WHCS are extracted. Finally, the prospects of WHCS are discussed.
\end{abstract}

\section{Introduction}

Current energy issues and environmental issues have become increasingly prominent, countries around the world have paid high attention to the development and utilization of renewable energy. Wind energy was highly appreciated for its great development potential by the governments in every country and has gradually occupied a larger proportion ${ }^{[1]}$, but at the same time wind energy also has the disadvantage of intermittency and storage difficulties ${ }^{[2]}$. Compared with wind energy, hydrogen has many advantages such as safety and environmental protection, heat energy concentration, easy storage and transportation, and has gradually become an important energy carrier and energy storage solution in the future ${ }^{[3]}$.

At present, the main source of hydrogen is still obtained through fossil fuels, which is not only low in purity, but also with adverse effects on the environment ${ }^{[4]}$. Hydrogen production using electricity generated by wind energy is the most promising technology that not only enables the storage and utilization of hydrogen but also connects directly with the natural gas supply network, it is considered to be the best way to enter the hydrogen era. In addition, hydrogen fuel cell vehicles are also receiving more and more attention ${ }^{[5]}$. Hydrogen production using wind power can not only create economic benefits, but also has the great significance of energy conservation and environmental protection and sustainable energy supply.

The paper will start from the structure of the WHCS and introduce the key technologies involved in the whole system to provide technical support for large-scale commercial operation in the future.

$\begin{array}{ll}\text { Nomenclature } \\ \text { WHCS } & \text { wind-hydrogen coupling system } \\ \text { ELE } & \text { electrolyzer } \\ \text { FC } & \text { fuel cell } \\ \text { PEM } & \text { proton exchange membrane }\end{array}$

\section{Fundamental structure of WHCS}

Figure 1 is the basic structure of WHCS ${ }^{[6]}$, in which includes wind turbine, electrolysis of water hydrogen equipment, buffer energy storage units, fuel cell(FC), hydrogen storage equipment and power conversion devices, etc. Wind turbine convert wind energy into electrical energy, which is the energy source of the whole system. The wind power is transformed into DC power that can be supplied to the electrolyzer (ELE) by the rectifying device. Due to the high stability of the working voltage of the ELE ${ }^{[7]}$, and intermittent and fluctuating wind energy and other factors, will result in 
unstable output power, the buffer storage device and the FC should be used to ensure the stability of the power supply to the ELE ${ }^{[8]}$.

The hydrogen produced by the ELE is stored through reasonable hydrogen storage methods. On one hand, it can be used as an energy carrier to enter the gas pipeline, ammonia and fertilizer manufacturing, metal smelting and other industries ${ }^{[9]}$; on the other hand, hydrogen can be used as the sources of FC power generation system, which ensures the stability of the entire system ${ }^{[10]}$.

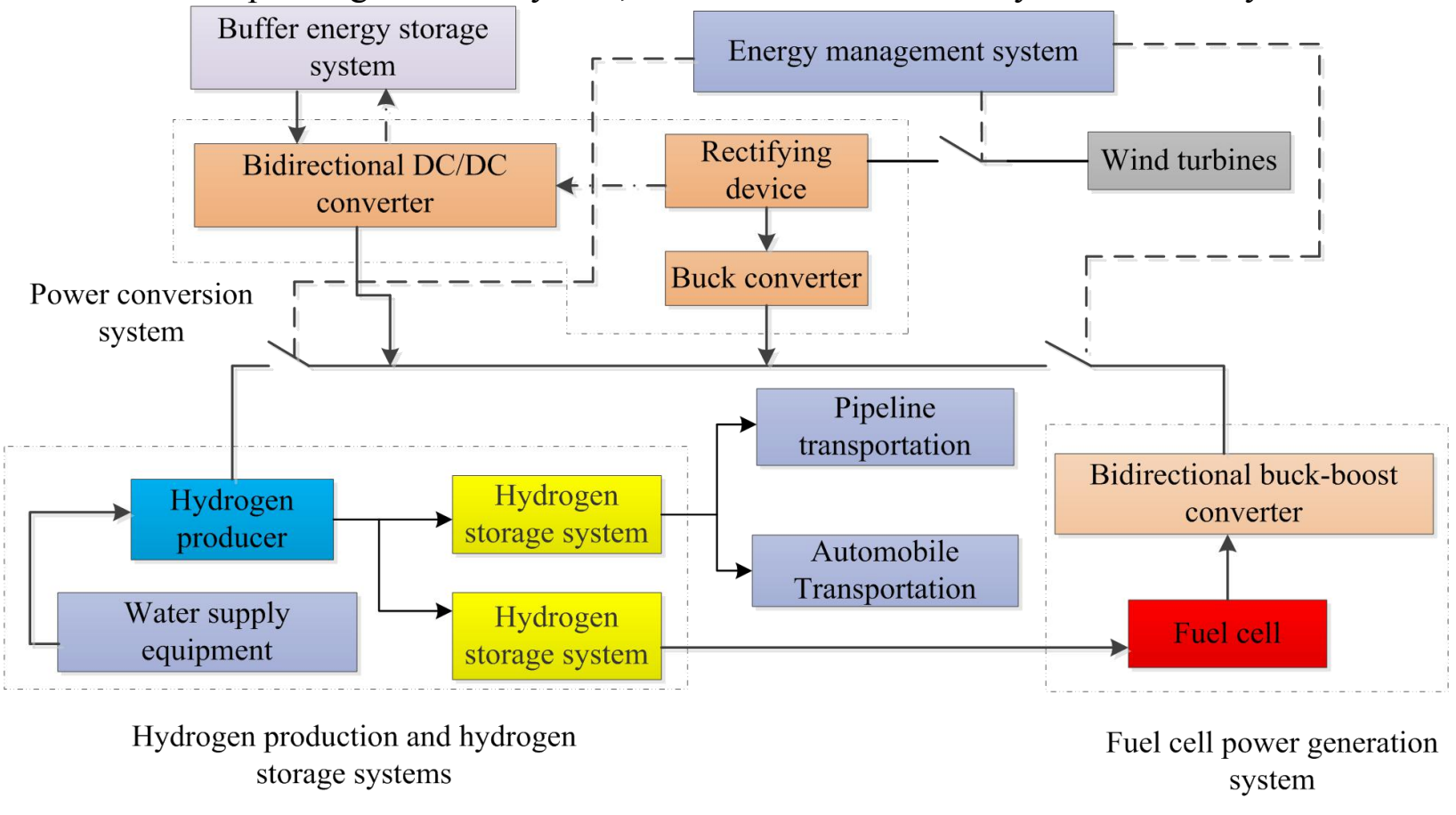

Fig.1 Fundamental structure of wind- hydrogen coupling system

\section{Research status}

The earliest countries researched on WHCS were some developed countries such as the United States, Canada, Britain, Norway, Germany and Iceland. In the early period of the research, they were mainly based on theoretical research. The research mainly focused on the qualitative analysis of wind power fluctuations and the impact of ELE and system capacity configuration ${ }^{[1]}$. The ENEA Casaccia Research Center in Italy built the earliest demonstration project of hydrogen production from wind power in $2000^{[12]}$.

After 2010, with the development and accumulation of related technologies, large-scale demonstration projects have been completed and research methods have been changed to verify the accuracy of the theory through the reliability assessment of demonstration projects, which has a great promoting to the progress of the technology of hydrogen production from wind power. The research scope also involves the joint control of various subsystems in the overall system, the energy management strategy, the improvement of the efficiency of the power converter, the economic analysis, etc ${ }^{[13]}$.

At present, WHCS has been commercialized. Germany built the world's first commercial wind power hydrogen multipurpose complementary project in 2013 named h2herten. The project produces $250 \mathrm{MWh}$ of electricity per year, with an annual output of $6500 \mathrm{Kg}$ of hydrogen and a total system operation efficiency of $58 \%-70 \%{ }^{[14]}$. In addition, the United States, Norway and other countries have also established the similar commercial project. The world's largest commercial wind power hydrogen project is building in Guyuan County, Hebei Province, China. The total investment of the project is 2.03 billion yuan, and the annual production capacity of hydrogen will be 17.52 million standard cubic meters. Now the wind turbines have been completed hoisting, hydrogen generator is being installed.

Moreover, it is worth noting that some developing countries such as Iran, Algeria, Bangladesh and Malaysia have also started to conduct research on WHCS and set up demonstration projects ${ }^{[15]}$. 
It can be seen that the utilization of hydrogen storage capacity by wind power is gradually receiving more and more widespread attention.

\section{Key technology analysis}

Stable hydrogen production technology

Hydrogen production system consists of a plurality of ELE composition, structures and functions are very complicated, in the entire WHCS has a core position. Hydrogen production system technical indicators largely affect the operation of the entire system, stable and efficient technology of electrolytic hydrogen production is the key to the overall system success ${ }^{[16]}$.

There are three types of ELE with relatively mature technologies, alkaline ELE, proton exchange membrane (PEM) ELE and high temperature ELE, working characteristics of three types of ELE are shown in Table $1^{[17]}$.

Table 1 Comparison of working characteristics of three types of ELE

\begin{tabular}{|c|c|c|c|c|c|c|c|}
\hline & Electrolyte & $\begin{array}{c}\text { Working } \\
\text { temperature }\end{array}$ & $\begin{array}{l}\text { Working } \\
\text { pressure }\end{array}$ & Efficiency & $\begin{array}{c}\text { Operating } \\
\text { power } \\
\text { range } \\
\end{array}$ & Advantage & Disadvantage \\
\hline Alkaline ELE & $\begin{array}{l}\text { Alkaline } \\
\text { solution }\end{array}$ & $60 \sim 80^{\circ} \mathrm{C}$ & $<3.0 \mathrm{MPa}$ & $65 \sim 75 \%$ & $5 \% \sim 100 \%$ & $\begin{array}{l}\text { The most } \\
\text { mature } \\
\text { technology }\end{array}$ & $\begin{array}{c}\text { Low current } \\
\text { density, long } \\
\text { switching time }\end{array}$ \\
\hline PEM ELE & Polymer & $50 \sim 80^{\circ} \mathrm{C}$ & $<3.0 \mathrm{MPa}$ & $50 \sim 70 \%$ & $0 \sim 100 \%$ & $\begin{array}{l}\text { Wide power } \\
\text { fluctuation }\end{array}$ & High cost \\
\hline $\begin{array}{c}\text { High } \\
\text { temperature } \\
\text { ELE } \\
\end{array}$ & $\begin{array}{l}\text { Yttrium oxide } \\
\text { or zirconium } \\
\text { oxide }\end{array}$ & $700 \sim 1000^{\circ} \mathrm{C}$ & & $70 \%$ & & $\begin{array}{c}\text { Can be used } \\
\text { for hot heat } \\
\text { source }\end{array}$ & $\begin{array}{c}\text { Operation } \\
\text { complexity is } \\
\text { high }\end{array}$ \\
\hline
\end{tabular}

At present, two kinds of large scale applications are alkaline ELE and PEM ELE. High-temperature ELE is still in the early stages of research, the technology is not yet mature. The minimum operating power of alkaline ELE is limited from $25 \%$ to $50 \%$ of the rated operating power. When the power is less than the minimum operating power limit, the ELE will be forced to shut down. In contrast, PEM ELEs are more adaptable to input power fluctuations but at a higher cost and are not yet commercially available in large scale, making them more suitable for small-scale experimental studies ${ }^{[18]}$.

How to obtain safe, stable and efficient hydrogen production technology, which is still an urgent problem to be solved on the condition of fluctuating input voltage and power, the current research in this field mainly focuses on two aspects in details:

(1) Research on ELE system requirements made by external power supply characteristics. From the perspective of ensuring the stable electrolysis system operation, improving the electrolysis efficiency and hydrogen purity, increasing system service life, power fluctuation influence on operating characteristics of the electrolysis system can be analyzed, which includes the ELE influence caused by wind power fluctuation, such as ELE input current, its input voltage, hydrogen production output and its system efficiency, in order to achieve the requirements for external power supply characteristics need by electrolysis system, to optimize further the external power supply characteristics, making it better to meet the stability and efficient operation of the electrolytic system.

(2) Optimize ELE performance further, concerning aspect should be considered, such as, how to improve ELE ability to adapt to external disturbances, how to extend the operating power range, and how to increase hydrogen production efficiency and reduce its operating costs.

\section{Safe hydrogen storage technology}

Hydrogen is gaseous in room temperature and atmospheric pressure, its density is only 1/14 of air, and hydrogen is flammable and explosive. Therefore, hydrogen storage is a crucial technology. There are currently 6 kinds of hydrogen storage methods commonly used: (1) compressed hydrogen; (2) liquidized hydrogen; (3) hollow glass microsphere; (4) metal hydrides; (5) hydrogen adsorption 
storage; (6) organic compounds hydrogen storage. Working characteristics of different kinds of hydrogen storage technology are shown in Table $2^{[19]}$.

Table 2 Comparison of working characteristics of different kinds of hydrogen storage technology

\begin{tabular}{|c|c|c|c|c|c|c|}
\hline & & $\begin{array}{l}\text { Storage } \\
\text { pressure }\end{array}$ & $\begin{array}{l}\text { Operating } \\
\text { temperature }\end{array}$ & $\begin{array}{c}\text { Mass } \\
\text { density }\end{array}$ & Advantages & Disadvantages \\
\hline \multirow{2}{*}{\multicolumn{2}{|c|}{ Compressed hydrogen }} & $15 \mathrm{MPa}$ & $20^{\circ} \mathrm{C}$ & $\leq 3 \%$ & \multirow{2}{*}{$\begin{array}{l}\text { Good economy, less } \\
\text { environmental } \\
\text { pollution }\end{array}$} & $\begin{array}{l}\text { Easy to leak, transport } \\
\text { containers prone to }\end{array}$ \\
\hline & & $70 \mathrm{MPa}$ & $20^{\circ} \mathrm{C}$ & $7 \% \sim 8 \%$ & & $\begin{array}{l}\text { "hydrogen } \\
\text { embrittlement" }\end{array}$ \\
\hline \multicolumn{2}{|c|}{ Liquidized hydrogen } & $\begin{array}{l}\text { Atmospheric } \\
\text { pressure }\end{array}$ & $-253^{\circ} \mathrm{C}$ & & High energy density & The cost is too high \\
\hline \multicolumn{2}{|c|}{ Hollow glass microsphere } & $62 \mathrm{MPa}$ & $370^{\circ} \mathrm{C}$ & $10 \%$ & $\begin{array}{l}\text { Lower cost, suitable } \\
\text { for hydrogen powered } \\
\text { vehicle systems }\end{array}$ & \multirow{2}{*}{$\begin{array}{l}\text { Process application } \\
\text { technology is more } \\
\text { difficult } \\
\text { High quality, high cost, } \\
\text { irreversible damage to } \\
\text { hydrogen }\end{array}$} \\
\hline Metal & Irides & $1 \mathrm{MPa}$ & $200 \sim 300^{\circ} \mathrm{C}$ & $2 \% \sim 7 \%$ & $\begin{array}{l}\text { High hydrogen storage } \\
\text { density }\end{array}$ & \\
\hline \multirow{3}{*}{$\begin{array}{c}\text { Hydrogen } \\
\text { adsorption } \\
\text { storage }\end{array}$} & $\begin{array}{l}\text { Carbon } \\
\text { nanotubes }\end{array}$ & $\begin{array}{l}\text { Atmospheric } \\
\text { pressure }\end{array}$ & $27^{\circ} \mathrm{C}$ & $14 \%$ & \multirow{3}{*}{$\begin{array}{l}\text { Moderate pressure, } \\
\text { light weight storage } \\
\text { container, the shape of } \\
\text { a large choice }\end{array}$} & \multirow{3}{*}{$\begin{array}{l}\text { High cost, difficult to } \\
\text { operate }\end{array}$} \\
\hline & $\begin{array}{c}\text { BN } \\
\text { nanotubes }\end{array}$ & $10 \mathrm{MPa}$ & $20^{\circ} \mathrm{C}$ & $1.8 \%$ & & \\
\hline & $\begin{array}{c}\text { Metal } \\
\text { organic } \\
\text { skeleton }\end{array}$ & $2 \mathrm{MPa}$ & $20^{\circ} \mathrm{C}$ & $1 \%$ & & \\
\hline \multicolumn{2}{|c|}{$\begin{array}{l}\text { Adsorption in liquid } \\
\text { organic metal hydrides }\end{array}$} & $4 \sim 4.5 \mathrm{MPa}$ & $210 \sim 260^{\circ} \mathrm{C}$ & $\begin{array}{l}5.9 \% \sim \\
6.4 \%\end{array}$ & $\begin{array}{l}\text { High density, safe, } \\
\text { convenient }\end{array}$ & $\begin{array}{l}\text { Involved in chemical } \\
\text { reactions, cumbersome } \\
\text { operation, hydrogen gas } \\
\text { containing impurities }\end{array}$ \\
\hline
\end{tabular}

By comparing various hydrogen storage methods, it can be seen that some hydrogen storage materials and technologies, such as hydrogen storage of glass microspheres, hydrogen storage of organic compounds and hydrogen storage of metal hydride, are still in the research and development stage of technology, there is a large gap between practical application and theoretical study, in terms of mass density and volumetric hydrogen storage density, working temperature, reversible cycle performance, and safety, the practical requirements can not be satisfied, and the cost of liquefying hydrogen storage is relatively high. In contrast, compressed hydrogen is the most suitable way for WHCS.

\section{Buffer energy storage technology}

The output power of wind turbine is uncertain and instable. Correspondingly, the input power of electrolysis equipment should be as stable as possible. Therefore, a certain capacity of buffer energy storage device needs to be configured to ensure the continuity and reliability of power supply. Commonly used buffer energy storage devices include batteries and supercapacitors.

Battery is the most commonly used buffer energy storage device. It has many advantages, such as large energy density and low cost, but it also has some shortcomings, such as short life, low power density, low temperature characteristics, harm to environment and regular maintenance. Compared with batteries, supercapacitors have higher power density, longer service life, faster charge and discharge speed, but less energy density ${ }^{[20]}$.

Therefore, a hybrid energy storage device composed of battery and super capacitor has become a hot research field at present, and it is applied to wind- hydrogen coupling system so that it can not only exert the advantages of large power density of supercapacitor and large energy density of battery, but also realize quick charge and discharge, extend the life of the buffer energy storage system, improve the performance of the buffer storage system. It is of great significance for 
improving the input power quality of the ELE and improving the stability of the whole windhydrogen system.

The commonly used hybrid energy storage device topology is shown in Figure.2, the battery is connected in parallel with the supercapacitor and then connected to the DC bus through a bidirectional DC-DC converter. This structure can sufficiently reduce the voltage drop of the supercapacitor and the battery, and simplify the voltage balance circuit. It is an ideal hybrid buffer energy storage device topology, the equivalent circuit is shown in Figure. $3^{[6]}$.

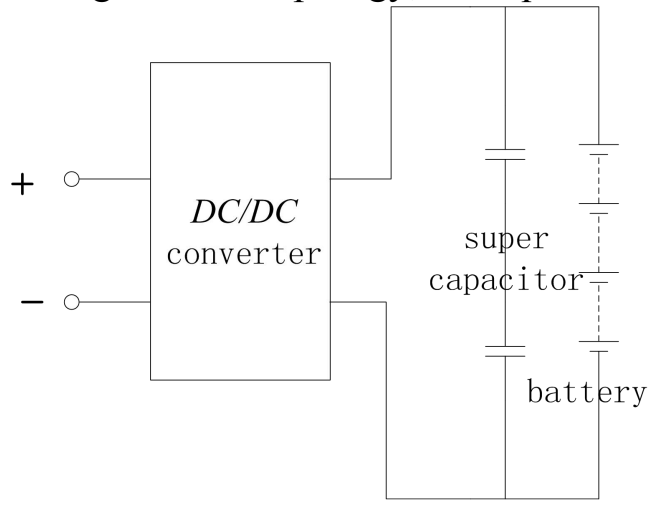

Fig.2 Topological structure of hybrid energy storage device

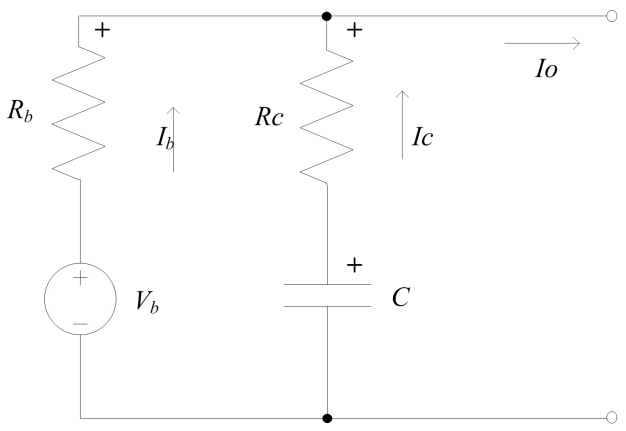

Fig.3 Hybrid energy storage device equivalent circuit

\section{FC technology}

In the WHCS, in addition to using a hybrid buffer energy storage device to supplement the stability of the system, the fuel cell is also an important auxiliary system. At present, fuel cells are mainly classified into the following categories according to the types of electrolytes: alkaline fuel cell (AFC), phosphoric acid fuel cell (PAFC), molten carbonate fuel cell (MCFC), solid oxide fuel cell (SOFC) and proton exchange membrane fuel cell (PEMFC). The characteristic parameters of various fuel cells are shown in Table. $3^{[21]}$.

Table. 3 Comparison of working characteristics of different kinds of fuel cell technology

\begin{tabular}{|c|c|c|c|c|c|}
\hline & AFC & PAFC & MCFC & SOFC & PEMFC \\
\hline Electrolyte & $\begin{array}{l}\text { Potassium } \\
\text { hydroxide } \\
\text { solution }\end{array}$ & Phosphoric acid & $\begin{array}{c}\text { Alkali metal } \\
\text { carbonate molten } \\
\text { mixture }\end{array}$ & $\begin{array}{l}\text { Oxygen ion and } \\
\text { conductive ceramics }\end{array}$ & $\begin{array}{l}\text { Proton exchange } \\
\text { membrane }\end{array}$ \\
\hline $\begin{array}{c}\text { Operating } \\
\text { temperature }\end{array}$ & $25^{\circ} \mathrm{C} \sim 90^{\circ} \mathrm{C}$ & $160^{\circ} \mathrm{C} \sim 220^{\circ} \mathrm{C}$ & $620^{\circ} \mathrm{C} \sim 660^{\circ} \mathrm{C}$ & $800^{\circ} \mathrm{C} \sim 1000^{\circ} \mathrm{C}$ & $25^{\circ} \mathrm{C} \sim 80^{\circ} \mathrm{C}$ \\
\hline $\begin{array}{l}\text { Temperature } \\
\text { classification }\end{array}$ & $\begin{array}{l}\text { Low temperature } \\
\text { fuel cell }\end{array}$ & $\begin{array}{c}\text { Low temperature } \\
\text { fuel cell }\end{array}$ & $\begin{array}{l}\text { High temperature } \\
\text { fuel cell }\end{array}$ & $\begin{array}{l}\text { High temperature } \\
\text { fuel cell }\end{array}$ & $\begin{array}{l}\text { Low temperature } \\
\text { fuel cell }\end{array}$ \\
\hline Efficiency & $60 \% \sim 70 \%$ & $36 \% \sim 42 \%$ & $60 \%$ & $60 \%$ & $50 \% \sim 60 \%$ \\
\hline $\begin{array}{l}\text { Current density } \\
\qquad\left(A \cdot \mathbf{c m}^{-2}\right)\end{array}$ & $0.1 \sim 0.9$ & $0.1 \sim 0.9$ & $0.1 \sim 0.9$ & $0.1 \sim 0.9$ & $0.1 \sim 0.9$ \\
\hline $\begin{array}{c}\text { Working } \\
\text { pressure /MPa }\end{array}$ & 0.1 & 0.1 & $0.1 \sim 1$ & 0.1 & $0.1 \sim 0.2$ \\
\hline Advantages & $\begin{array}{l}\text { Low cost, quick } \\
\text { start, reliable } \\
\text { performance }\end{array}$ & Longer service life & $\begin{array}{l}\text { High fuel } \\
\text { adaptability and high } \\
\text { utilization value of } \\
\text { waste heat }\end{array}$ & $\begin{array}{l}\text { Electrolytes are solid, } \\
\text { without material } \\
\text { corrosion and } \\
\text { electrolyte corrosion }\end{array}$ & $\begin{array}{l}\text { Fast start, high } \\
\text { power density, long } \\
\text { life, reliable } \\
\text { operation }\end{array}$ \\
\hline Disadvantages & $\begin{array}{l}\text { Short life, easy } \\
\text { poisoning } \\
\text { catalyst }\end{array}$ & $\begin{array}{c}\text { Long start time } \\
\text { and low utilization } \\
\text { value of waste } \\
\text { heat }\end{array}$ & $\begin{array}{c}\text { Electrolytes are } \\
\text { corrosiveness and } \\
\text { short life }\end{array}$ & $\begin{array}{l}\text { High temperature } \\
\text { conditions, material } \\
\text { selection harsh, high } \\
\text { cost }\end{array}$ & $\begin{array}{l}\text { High cost, easy } \\
\text { poisoning catalyst }\end{array}$ \\
\hline
\end{tabular}


In the WHCS, low temperature FCs including AFC, PAFC, PEMFC, for its features like short start-up time, reliable performance and adaptability to intermittent operation strong, has gradually been widely used.

However, due to technical reasons, the response time of FC still can not fully catch the fluctuation of wind instantaneous power. The combined application of FC and hybrid energy storage system will overcome this shortcoming and achieve higher power quality ${ }^{[2]}$.

\section{System coordinated control and power conversion technology}

The whole WHCS is complex, including a large number of subsystems. In order to achieve stable system operation, improve the overall system efficiency and maximize the capacity of hydrogen production, it's necessary to achieve coordinated control among subsystems, including control the output and shutdown of the wind turbine through the dispatching system, exchange data and logic judging with the central coordinated control system through the communication network to confirm whether the wind power can be used to produce the hydrogen. Besides, depending on the operating conditions of the hydrogen storage system and hydrogen produce system, determines the process coordination between the FC system and the hybrid buffer energy storage system ${ }^{[23]}$.

Meanwhile, in order to achieve intelligent optimal operation, ensure reliable power supply of ELE, research the topological transformation of power conversion system from wind turbine output to ELE input is necessary, including optimize the topology structure of wind power rectification, energy storage power regulation, electrolytic power supply and so on ${ }^{[24]}$. Now the fact that some existing topologies have not yet been optimized result in low power converter efficiency, low integration, high energy consumption and other shortcomings, a more efficient, stable and low cost power conversion system topology should be built to make it more suitable for electrolysis equipment and improve the efficiency of the whole system.

\section{Techno-economic appraisal}

At present, the demonstration project of the WHCS has been set up, selecting the index of technical economic evaluation sensitivity and completing a set of technical and economic evaluation system suitable for WHCS is of great guiding significance to the engineering technology and industrial scale popularization of $\mathrm{WHCS}^{[25]}$.

\section{Prospects of WHCS}

WHCS is in its development stage, but its characteristics are adapted to the needs and directions of future power development, broad development prospects, embodied in the following areas:

1. An effective utilization form of large-scale wind power. Hydrogen as a large-scale energy storage can effectively solve the problem of wind power curtailment. Meanwhile, hydrogen as secondary energy, will further enter the concerning field, such as chemical industry, metallurgy, aviation and new energy vehicles.

2. With considerable environmental and economic benefits. Over $95 \%$ of the world's hydrogen production is highly dependent on fossil fuels now, the resulting direct carbon emissions amount to billions of tons, causing serious environmental pollution. The use of wind power to make hydrogen is the most environmentally friendly way, which will not only create economic benefits, but also protect the environment ${ }^{[26]}$.

\section{Conclusions}

This paper reviews the development of WHCS. Firstly introduces the basic structure and research status of WHCS, then summarizes its key technologies, finally analyzes the prospects of WHCS. The paper focus on 
key and difficult issues in research field, the concerning conclusions and prospects are shown as follows.

1. Stable hydrogen production technology on the condition of power fluctuation. The alkaline ELE which has been put into commercial operation has a long response time and narrow operating power, PEM ELEs are expensive and can not be used in large-scale applications. Getting stable hydrogen production technology under power fluctuation is the key problem to be solved in the future.

2. High-capacity and high-density hydrogen storage technology. The widely used hydrogen storage method is compressed storage, but with the progress of technology and the reduction of cost, some other hydrogen storage methods will gradually be used in the wind -hydrogen coupled system as well.

3. The coordinated control technology between FC and hybrid energy storage device. The FC and the hybrid energy storage device are introduced into the WHCS to stabilize the input power of the ELE, realizing the coordinated control between FC and hybrid energy storage device is of great significance for sustainably running of the system.

4. Optimize the power transformation topology of WHCS. From the perspective of improving the power conversion efficiency, achieving power conversion integrated, modular and standardized, the power conversion topology which are more efficient, lower cost, easier to control should be proposed, it will provide important support for the commercialization of WHCS.

WHCS has broad prospects for development, concerned by more and more scientific research institutions, there is no doubt that with the solution of key technologies, it will certainly be more widely used in the near future.

\section{References}

[1].Ji-Ping L U, Bai S H. Modeling and Simulation of Conjoint Independent Power Generation System Consisting of Power Generation by Wind Energy,Solar Energy and Hydrogen Energy[J]. Power System Technology, 2007, 31(22):75-79.

[2].Yuan T, Li G, Zhang Z, et al. Optimal Modeling on Equipment Investment Planning of Wind Power-Hydrogen Energy Storage and Coal Chemical Pluripotent Coupling System[J]. Transactions of China Electrotechnical Society, 2016.

[3].Zhao Y, Meng B, Chen L, et al. Utilization status of hydrogen energy[J]. Chemical Industry \& Engineering Progress, 2015.

[4].Han W.Development and technology research of the World Hydrogen Energy[J].Contemporary Chemical Industry,2016, 45(6)

[5].Nikolaidis P, Poullikkas A. A comparative overview of hydrogen production processes[J]. Renewable \& Sustainable Energy Reviews, 2017, 67:597-611.

[6].Chong L W, Wong Y W, Rajkumar R K, et al. Hybrid energy storage systems and control strategies for stand-alone renewable energy power systems[J]. Renewable \& Sustainable Energy Reviews, 2016, 66:174-189.

[7].Hassan S Z, Li H, Şuayb Çağriyener, et al. Integration and simulation of wind with hydrogen/supercapacitor storage hybrid system[C]// International Conference on Electrical Engineering. IEEE, 2017:1-6.

[8].Mendis N, Sayeef S, Muttaqi K M, et al. Hydrogen energy storage for a permanent magnet wind turbine generator based autonomous hybrid power system[C]// Power and Energy Society General Meeting. IEEE, 2011:1-7. 
[9].Ziogou C, Ipsakis D, Elmasides C, et al. Automation infrastructure and operation control strategy in a stand-alone power system based on renewable energy sources[J]. Journal of Power Sources, 2011, 196(22):9488-9499.

[10].Pino F J, Valverde L, Rosa F. Influence of wind turbine power curve and ELE operating temperature on hydrogen production in wind-hydrogen systems[J]. Journal of Power Sources, 2011, 196(9):4418-4426.

[11].Modeling and control of a wind fuel cell hybrid energy system - Iqbal, M. T. Renewable Energy, 200, 28, (2), 223-237[J]. 2003(3):162.

[12].Dutton A G, Bleijs J A M, Dienhart H, et al. Experience in the design, sizing, economics, and implementation of autonomous wind-powered hydrogen production systems [J]. International Journal of Hydrogen Energy, 2000, 25(8):705-722.

[13].Cai G, Kong L, Yu X, et al. Overview of Research on Wind Power Coupled with Hydrogen Production Technology[J]. Automation of Electric Power Systems, 2014, 38(21):127-135.

[14].Huss A. Wind power and hydrogen: complementary energy sources for sustainable energy supply[J]. Fuel Cells Bulletin, 2013, 2013(4):12-17.

[15].S. Kélouwani, K. Agbossou, R. Chahine. Model for energy conversion in renewable energy system with hydrogen storage[J]. Journal of Power Sources, 2005, 140(2):392-399.

[16].Das B K, Hoque N, Mandal S, et al. A techno-economic feasibility of a stand-alone hybrid power generation for remote area application in Bangladesh[J]. Energy, 2017, 134.

[17].Lewandowska-Bernat A, Desideri U. Opportunities of Power-to-Gas technology[J]. Energy Procedia, 2017, 105:4569-4574.

[18].Sarrias-Mena R, Fernández-Ramírez L M, García-Vázquez C A, et al. ELE models for hydrogen production from wind energy systems[J]. International Journal of Hydrogen Energy, 2015, 40(7):2927-2938.

[19].Jing L,Dong J Z,Hydrogen storage materials and research progress[J].Journal of Suihua University,2017, 37(8)

[20].Zhang C Z. Modeling and simulation for solar-hydrogen system[D]. Southwest Jiaotong University.2009

[21].Chong L W, Wong Y W, Rajkumar R K, et al. Hybrid energy storage systems and control strategies for stand-alone renewable energy power systems[J]. Renewable \& Sustainable Energy Reviews, 2016, 66:174-189.

[22].Cunpu L I, Chen J, Li L I, et al. Key materials and progress of fuel cells[J]. Science \& Technology Review, 2017.

[23].Zhang J L, Yue W U, Dong-Lian Q I. Design of Wind Power Hydrogen Coupled with Fuel Cell Microgrid Experimental System[J]. Research \& Exploration in Laboratory, 2017.

[24].Gyawali N, Ohsawa Y. Integrating Fuel Cell/ELE/Ultracapacitor System Into a Stand-Alone Microhydro Plant[J]. IEEE Transactions on Energy Conversion, 2010, 25(4):1092-1101.

[25].Shi J L, Gao H. Economic Analysis on Wind Power for Hydrogen Production [J]. Energy of China, 2015, 37(2)

[26].Thanapalan K, Zhang F, Carr S.An overview of renewable energy technologies and hydrogen economy.International Conference on Renewable Energies and Power Quality.ICREPQ' 13.2013. 